\title{
Increased Regulatory and Decreased CD8+ Cytotoxic T Cells in the Blood of Patients with Idiopathic Pulmonary Arterial Hypertension
}

\author{
Silvia Ulrich ${ }^{\mathrm{a}, \mathrm{b}}$ Mark R. Nicolls ${ }^{\mathrm{a}}$ Laima Taraseviciene ${ }^{\mathrm{a}}$ Rudolf Speich $^{\mathrm{b}}$ Norbert Voelkel $^{\mathrm{a}}$ \\ a University of Colorado Health Science Center, Denver, Colo., USA; ${ }^{b}$ Department of Internal Medicine and \\ Pulmonology, University Hospital Zürich, Zürich, Switzerland
}

For editorial comment see p. 253

\section{Key Words}

$\mathrm{CD} 4 \cdot \mathrm{CD} 8 \cdot \mathrm{CD} 25 \cdot$ FoxP3 $\cdot$ Idiopathic pulmonary arterial hypertension $\cdot$ Regulatory $T$ cells

\begin{abstract}
Background: An association between pulmonary arterial hypertension (PAH) and various immune disorders is well established. Recently, the role of an intact immune system in protecting against pulmonary angioproliferation was shown in an animal model. Objective: To elucidate the role of T cells in human PAH, we comparatively studied $T$ cell subclasses with emphasis on regulatory $T$ cells $\left(T_{\text {reg }}\right)$ in the peripheral blood of patients with idiopathic pulmonary arterial hypertension (IPAH) and healthy controls. Methods: Isolated peripheral blood mononuclear cells from 36 patients diagnosed with IPAH and 33 healthy controls were stained with fluorescently labeled monoclonal antibodies against superficial $\mathrm{T}$ cell markers (CD3, CD4, CD8, CD25) and FoxP3, the intracellular marker of $\mathrm{T}_{\text {reg }}$ cells. The relative cell distribution was analyzed by flow cytometry. The functionality of patient and control $\mathrm{T}_{\text {reg }}$ cells was assessed by coculture of $\mathrm{T}_{\text {reg }}$ with nonregulatory $T$ cells from the same individual. Results: Significantly less CD8+ T cells $(p=0.02)$ and more CD25hi+ and FoxP3+CD4+ T cells were found in the peripheral blood of patients compared with controls ( $p=0.009$ and $p<0.001$, respectively). The percentage of FoxP3 + cells within the $\mathrm{CD} 25 \mathrm{hi}+\mathrm{CD} 4+\mathrm{T}_{\text {reg }}$
\end{abstract}

cells was similar. $T_{\text {reg }}$ cell functionality was equal in patients and controls. Conclusion: Our findings of decreased CD8+ T cells and increased $\mathrm{T}_{\text {reg }}$ cells in the peripheral blood of patients with IPAH are novel and may have implications for directing future research in the field to elucidate the differential role of T cells and the immune system in IPAH.

Copyright $\odot 2007$ S. Karger AG, Basel

\section{Introduction}

Idiopathic pulmonary arterial hypertension (IPAH) is a progressive disease with a dismal prognosis ultimately leading to right ventricular failure and death. Lumen obliteration of the microscopically fine precapillary arterioles due to endothelial proliferation and formation of complex vascular lesions are important aspects of the pathobiology [1-3]. Although germline mutations of the gene encoding bone morphogenetic protein receptor II (BMPRII), a member of the transforming growth factor superfamily, have been identified in some patients with familial and sporadic IPAH [4-7], how germline BMPRII mutations promote the development of $\mathrm{PAH}$ remains unclear. Thus, other mechanisms contributing to the pathogenesis of PAH are of great interest and currently under investigation. One controller of pulmonary hypertension may be the immune system, based on the following facts:

\section{KARGER}

Fax +4161306 1234 E-Mail karger@karger.ch www.karger.com
(C) 2007 S. Karger AG, Basel 0025-7931/08/0753-0272\$24.50/0

Accessible online at: www.karger.com/res
Silvia Ulrich, MD

Department of Internal Medicine, Division of Respiratory Medicine

University Hospital of Zürich, Raemistrasse 100

CH-8091 Zürich (Switzerland)

Tel. +41 4425541 62, Fax +41 4425585 19, E-Mail ulris@bluewin.ch 
$\mathrm{PAH}$ is associated with a number of collagen vascular autoimmune disorders [8-14] (where BMPRII mutations are not prevalent) [15]; secondly, patients with PAH often have antinuclear, antiphospholipid or other autoantibodies [16-20]; plexiform lesions are surrounded by immune cells [3, 21-23], and alterations in blood cytokines have been reported [24]. PAH also occurs in association with HIV infection, where CD4 lymphocytes and regulatory T cells are depleted [25]. Recently, we showed that athymic rats, which lack $\mathrm{T}$ lymphocytes, develop severe angioproliferative PAH when exposed to the vascular endothelial growth factor inhibitor SU5416 in a normoxic environment [26-28]. If the immune system of these athymic rats was reconstituted by injecting splenocytes from euthymic syngeneic animals before administration of SU5416, the animals were protected from the development of exuberant pulmonary vascular lesions [27]. Hence, an intact immune system and especially the T cell compartment seem to play a role in the development of $\mathrm{PAH}$.

How the immune system discriminates between self and non-self and establishes and maintains unresponsiveness to self has been a key issue in immunology since the proposition of the clonal selection theory [29]. The contribution of regulatory (or suppressor) $\mathrm{T}$ cells $\left(\mathrm{T}_{\text {reg }}\right)$ or even their existence as a cellular entity has been controversial until recently, mainly because of the lack of a reliable marker to identify them and the ambiguity of their functions at the molecular level [30]. Research in the last years has discovered several cell surface markers that could operationally differentiate $\mathrm{T}_{\text {reg }}$ from other $\mathrm{T}$ cells $[31,32]$. Recently, FoxP3, a transcription factor of the forkhead/winged-helix family, has been identified as a very specific marker of $\mathrm{T}_{\text {reg }}$ cells [33-36]. FoxP3 $+\mathrm{T}_{\text {reg }}$ cells have been shown to be essential for the induction and maintenance of self-tolerance and prevention of T-cell-mediated autoimmunity [36-38]. In healthy humans, this population accounts for $5-10 \%$ of the peripheral CD4+ T cells. Alterations in the number of $\mathrm{T}_{\text {reg }}$ cells in the peripheral blood have been reported in various immune disorders, some of them associated with $\mathrm{PAH}$, and cancer [39-45]. Whereas $\mathrm{T}_{\text {reg }}$ cells were found to be qualitatively and/or quantitatively deficient in many autoimmune diseases (e.g., multiple sclerosis, graft versus host disease, systemic lupus erythematosus, type I diabetes or rheumatoid arthritis) [46-49], they have been shown to be increased in some tumors and infections $[41,42,45,46$, $50,51]$. The aim of the present study was to investigate peripheral blood $\mathrm{T}$ lymphocyte subsets with emphasis on $\mathrm{T}_{\text {reg }}$ cells in IPAH compared with healthy controls in the hope of elucidating one step toward a better understanding of the role of the immune system in human PAH.

\section{Material and Methods}

Study Design and Subjects

The present study is a prospective clinical investigation on lymphocyte subsets in the peripheral blood of patients compared with healthy controls. Patients were diagnosed with IPAH according to the WHO classification [52] if the mean pulmonary artery pressure was $\geq 25 \mathrm{~mm} \mathrm{Hg}$ along with a pulmonary arterial occlusion pressure $\leq 15 \mathrm{~mm} \mathrm{Hg}$ assessed by right heart catheterization, and if an extensive clinical work-up did not reveal other conditions responsible for pulmonary hypertension [52]. Healthy volunteers working at the University of Colorado Health Sciences Center served as controls. The study was approved by the local institutional review board and subjects gave their written informed consent.

Blood Samples and Analysis of Lymphocyte Subsets

Venous blood samples were collected in heparin-treated tubes from each subject, and peripheral blood mononuclear cells (PBMCs) were separated immediately using Histopaque (SigmaAldrich, St. Louis, Mo., USA) density gradient centrifugation. PBMCs were either processed within $24 \mathrm{~h}$ (18 patients and 23 controls) or frozen at $-20^{\circ} \mathrm{C}(18$ patients and 10 controls) for up to 1 month in PBMC freezing medium (Cambrex, Walkersville, Md., USA).

The FACS Calibur 4-color flow cytometer (BD Biosciences, N.Y., USA) was used to identify the cell type. Two million PBMCs each were stained with fluorescently labeled monoclonal antibodies (mAbs) directed against superficial activation markers (antiCD3-PE, anti-CD8-FITC, anti-CD4-perCP, anti-CD25-APC) and against the intranuclear marker anti-FoxP3-PE. The superficial markers were all purchased from $\mathrm{BD}$ Bioscience, whereas the intracellular marker was purchased from eBioscience (San Diego, Calif., USA). In brief, for superficial stains, cells were incubated in the dark at $-4^{\circ} \mathrm{C}$ for $30 \mathrm{~min}$ with $\mathrm{mAbs}$ at concentrations recommended by the manufacturer, washed twice with phosphatebuffered saline, blocked with $1 \%$ bovine serum albumin and thereafter fixed in phosphate-buffered saline with $1 \%$ formaldehyde and $0.01 \% \mathrm{NaN}_{3}$ and stored at $-4^{\circ} \mathrm{C}$ in the dark until analysis. For intracellular staining with anti-FoxP3, cells were stained against the superficial markers CD4 and CD25 as above. After 1 wash, cells were permeabilized, washed, blocked and stained using the buffers and instructions provided by the manufacturer (eBioscience) and thereafter fixed and stored as above. Flow cytometric analysis was performed within $24 \mathrm{~h}$. The flow cytometry data were analyzed using CellQuest software (BD Bioscience).

\section{Cell Proliferation Assay}

PBMCs were obtained from patients and controls as described above. CD4+CD25hi+ $\left(\mathrm{T}_{\mathrm{reg}}\right.$ ) and CD4+CD25hi- (responders) $\mathrm{T}$ cells were separated from PBMCs using magnetic separation by RoboSep (StemCell, Vancouver, Canada). Cell purity was assessed by flow cytometry using fluorescently labeled anti-CD4-perCP and anti-CD25-APC mAbs. Before seeding, U-bottom 96-well plates were coated with anti-CD3 $\left(0.5 \mu \mathrm{g} / \mathrm{ml}\right.$ for $4-16 \mathrm{~h}$ at $\left.-4^{\circ} \mathrm{C}\right)$. To measure cell proliferation, $1 \times 10^{4} \mathrm{CD} 4+\mathrm{CD} 25 \mathrm{hi}-\mathrm{T}$ cells/well were seeded, and then increasing numbers (1:0, 1:8, 1:4, 1:2) of $\mathrm{CD} 4+\mathrm{CD} 25 \mathrm{hi}+\left(\mathrm{T}_{\text {reg }}\right)$ cells were added and cocultured for $48 \mathrm{~h}$. Cells were cultured in a final volume of $200 \mu \mathrm{l}$ PBMC cell culture medium consisting of RPMI 1640 with glutamine containing $10 \%$ 
Fig. 1. Differential frequencies of CD4+ and CD8+ T lymphocyte (CD3+) subsets for IPAH patients and controls. n.s. $=$ Not significant.

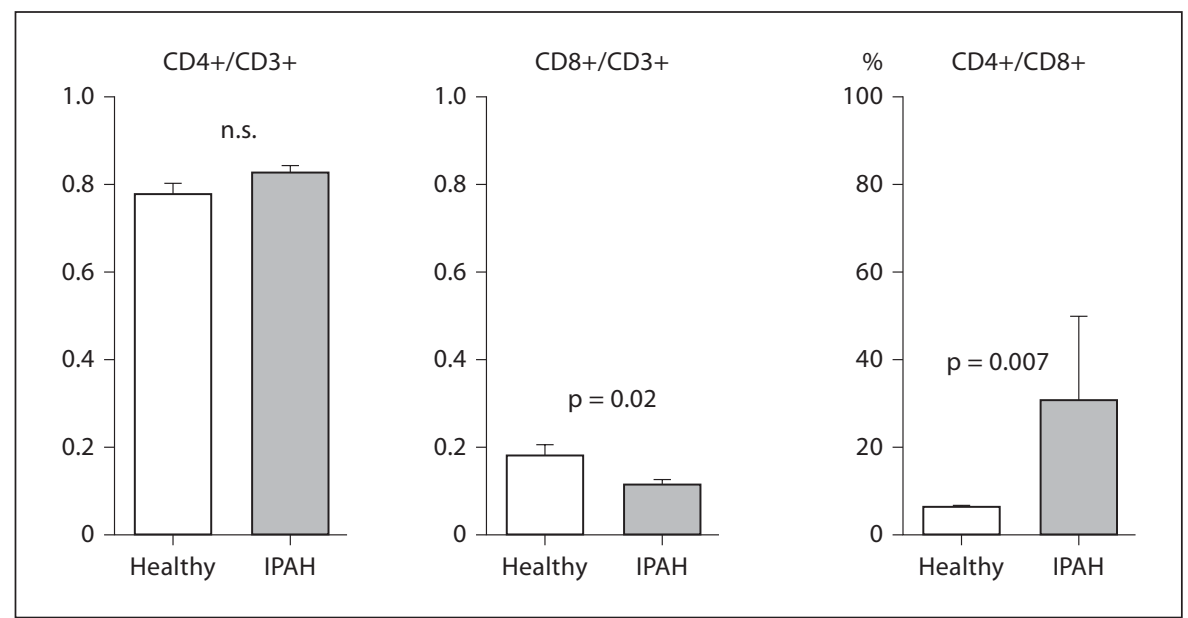

human $\mathrm{AB}$ serum, 1\% HEPES $1 \mathrm{M}, 1 \%$ penicillin-streptomycinglutamine (Cambrex, Ariz., USA) and $1 \% \mathrm{Na}$ pyruvate $100 \mathrm{M}$ at $37^{\circ} \mathrm{C}$ in $5 \% \mathrm{CO}_{2}$ for $48 \mathrm{~h}$. Thereafter, cell plates were centrifuged at $1,400 \mathrm{rpm}$ for $8 \mathrm{~min}$. Cell proliferation was measured using CyQuant proliferation kit (Invitrogen, Molecular Probes, N.Y., USA).

\section{Data Presentation and Statistics}

Baseline characteristics and lymphocyte counts are presented as means \pm standard deviation. SPSS version 11.5 and GraphPad Prism version 4.0 software packages were used for statistical analysis and graph editing. Mann-Whitney U, Student's $t$ and Wilcoxon tests were used for comparative analysis between groups as appropriate. A p value $<0.05$ was considered statistically significant.

\section{Results}

\section{Patient Characteristics}

We enrolled 36 patients ( 26 females) and 33 healthy controls ( 15 females) at a mean age of $51 \pm 11$ and $43 \pm$ 9 years $(\mathrm{p}=0.05)$ in the study upon informed consent. Pulmonary hemodynamic characteristics of the patients were: mean pulmonary arterial pressure $49 \pm 14$ $\mathrm{mm} \mathrm{Hg}$, cardiac index $2.3 \pm 0.7 \mathrm{l} \cdot \mathrm{min}^{-1} \cdot \mathrm{m}^{-2}$, pulmonary vascular resistance $858 \pm 364 \mathrm{dyn} \cdot \mathrm{s} \cdot \mathrm{m}^{-5}$, pulmonary capillary occlusion pressure $8.9 \pm 4.1 \mathrm{~mm} \mathrm{Hg}$, right arterial pressure $8.1 \pm 5.4 \mathrm{~mm} \mathrm{Hg}$, arterial oxygen saturation $93 \pm 6 \%$, and mixed venous oxygen saturation $54 \pm 9 \%$. The mean time between the diagnostic right heart catheter date and the blood analysis was 10 \pm 10 months. Twenty-five patients (68\%) were treated with continuous intravenous epoprostenol, 3 of which had a combination therapy with oral bosentan. Two pa- tients (5\%) were treated with inhaled iloprost and 1 patient with sildenafil. Eight patients (22\%) did not receive a specific therapy for $\mathrm{PAH}$.

\section{Differential Frequencies of Lymphocyte Subclasses and $T_{\text {reg }}$ Cells}

Within the T cell subset, we found a tendency toward an increase in the percentage of CD4+ T cells in the peripheral blood of IPAH versus controls $(83 \pm 1.7$ vs. 78 $\pm 2.7 \% ; \mathrm{p}=0.11)$ at the expense of a significant decrease in CD8+ T cells ( $11 \pm 1.2$ vs. $18 \pm 2.5 \%$; $p=0.02)$ (fig. 1 ). The CD4/CD8 relation consecutively decreased $(\mathrm{p}=$ 0.007) (fig.1). Within the CD4+ T cell compartment, we found significantly more CD25hi+ $\mathrm{T}$ cells in patients compared with controls $(5.9 \pm 0.8$ vs. $3.5 \pm 0.3 \%$; $\mathrm{p}=$ 0.009 ) and a significantly increased number of FoxP3+ $\mathrm{T}_{\text {reg }}$ cells (10.1 \pm 1.5 vs. $4.5 \pm 0.35 \%$ of all CD $4+\mathrm{T}$ cells; $\mathrm{p}<0.001$ ) (fig. 2, 3). However, the percentage of FoxP3+ cells within the CD25hi+CD4+ $\mathrm{T}_{\text {reg }}$ cells in each group was similar $(61.6 \pm 2.8$ vs. $62.0 \pm 4.0 \%$; $=0.93)$. We found no difference in the lymphocyte subsets between patients who received PAH-specific therapy and therapynaïve patients. We neither found a difference in the lymphocyte subsets between patients with a time span between the diagnostic pulmonary artery catheter of more and less than 10 months.

\section{Proliferation Assay}

The proliferation assay of $\mathrm{T}$ lymphocytes from the blood of IPAH patients $(n=16)$ and healthy controls $(n=$ 13) was performed in triplicate. Test performance was monitored by a respective linear rise of relative light units with increasing standard number of cells/well. Patient 


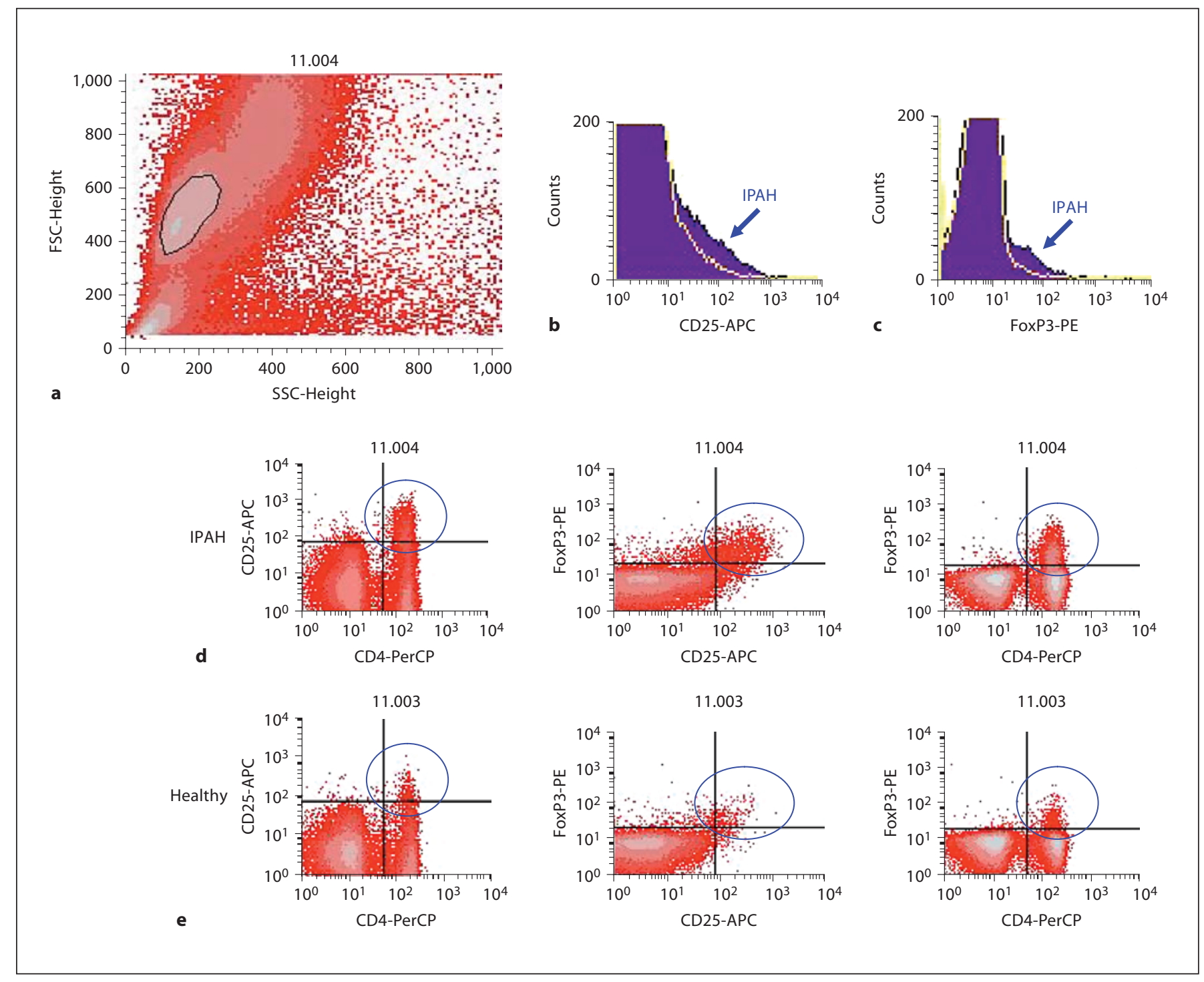

Fig. 2. Representative samples of flow cytometric findings are shown for a patient with IPAH and a healthy control. a A typical forward side scatter with the gated lymphocytes encircled in black. b, c Typical histograms of CD25+ (b) and FoxP3+ (c) T cells from IPAH patients, indicating also the typical histogram in healthy controls (Ctrl). d, e Four field charts show typical cell distributions for the markers of interest (CD4, CD25 and FoxP3) for IPAH patients (d) and healthy controls (e).
CD4+CD25- T cells (responder cells) were found to have proliferated slightly more than cells from healthy controls $(9,731 \pm 2,638$ vs. 7,715 $\pm 1,310$ relative light units); however, the difference was not statistically significant $(\mathrm{p}=0.6)$. Addition of increasing numbers of $\mathrm{CD} 4+\mathrm{CD} 25+\mathrm{T}$ cells equally suppressed the anti-CD3induced proliferation of CD4+CD25- T cells in patients or controls (data not shown).

\section{Discussion}

In the present study, we found an increased percentage of $\mathrm{CD} 25$ high+ and FoxP3+CD4 $+\mathrm{T}_{\text {reg }}$ cells and a decreased percentage of $\mathrm{CD} 8+\mathrm{T}$ cells in the peripheral blood of patients with IPAH compared with healthy controls. The percentage of FoxP3 $+\mathrm{T}$ cells within the CD25+CD4+ T cell subset of IPAH and controls was comparable, which still signifies a higher total percentage of FoxP3+CD25+ $\mathrm{T}_{\text {reg }}$ cells in IPAH due to their higher 
Fig. 3. Differential frequencies of lymphocyte subclasses for IPAH patients and controls for CD25+ and FoxP3+CD4+ and FoxP3+CD25+CD4+ T cells. $p$ values indicate the level of significance of the difference (2-sided t test).

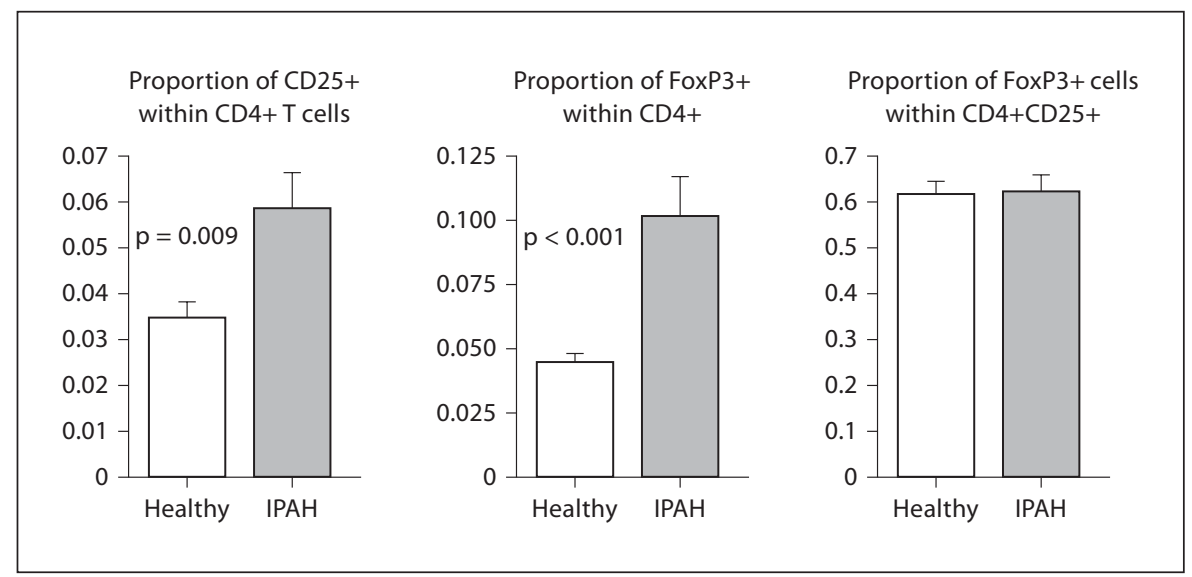

percentage of CD25+ T cells (fig. 3). Our findings of a differential prevalence of some of the $\mathrm{T}$ cell subsets between IPAH and controls may point toward a pathogenetic role of the $\mathrm{T}$ cell compartment in $\mathrm{PAH}$, as has recently been demonstrated in an animal model [27]. However, we are aware that the interpretation of our findings in the peripheral blood of IPAH compared with controls is difficult and does not allow to draw firm conclusions about pathogenetic pathways, causes and consequences in the pulmonary vasculature. Nevertheless, we present some speculations below in the hope to inspire future research in the field.

The transcription factor FoxP3, which is expressed by the majority of $\mathrm{CD} 25+\mathrm{CD} 4+$ and also by a fraction of CD25-CD4+ $\mathrm{T}$ cells, is the most reliable and specific marker of naturally occurring $\mathrm{T}_{\text {reg }}$ cells $[35,37]$. The overall increase in FoxP3+CD4+ T cells in the blood of IPAH with an unchanged percentage of FoxP3+ cells within the $\mathrm{CD} 25+\mathrm{CD} 4+\mathrm{T}$ cell subset indicates that at least some of the increased number of the FoxP3+ T cells can be attributed to a peripheral conversion of CD25-CD4+ T cells into $\mathrm{T}_{\text {reg }}$ cells [53]. Conversion of CD4+ $\mathrm{T}$ cells in the periphery into $\mathrm{T}_{\text {reg }}$ cells by de novo FoxP3+ expression has been described in various diseases in order to control an exaggerated immune response $[36,37,53,54]$. Recent reports underscore that $\mathrm{T}_{\text {reg }}$ cells not only play a central role in the maintenance of immunotolerance [30, 36-38, 54], but that they are also potent inhibitors of antitumor and possibly antiviral immune responses [25, 42-45]. Monoclonal cancer-like endothelial proliferation is a key histopathological finding in IPAH $[1,3,23,55]$.

Therefore, we speculate that the increase in $\mathrm{T}_{\text {reg }}$ cells in the peripheral blood of IPAH could be attributed to the necessity to suppress any self-reactive T cells (possibly to- wards the cancer-like endothelial proliferation) in analogy to the postulated function of increased $\mathrm{T}_{\text {reg }}$ cells in cancer $[56,57]$. Tumor immune surveillance by $\mathrm{T}_{\text {reg }}$ cells is apparently insufficient to suppress the emergence of cancer. A possible clue to this issue is the finding that many tumor antigens are recognized by autologous cytotoxic $\mathrm{T}$ cells directed against normal self-constituents [57], thus indicating that tumor immunity is to some degree also autoimmunity. Whether cytotoxic $\mathrm{T}$ cells directed towards self-constituents might be involved in the pathogenesis of PAH is not known to date, but several findings already point toward a role of autoimmunity in $\mathrm{PAH}$ [8]. Our findings of increased $\mathrm{T}_{\text {reg }}$ cells in IPAH support this hypothesis. A functional hallmark of naturally occurring $\mathrm{T}_{\text {reg }}$ cells is that they suppress the activation and expansion of self-reactive $\mathrm{T}$ cells and inhibit the development of autoimmune disease [37]. The high sensitivity of $\mathrm{T}_{\text {reg }}$ cells toward self- and non-self antigens and their high activity of bystander suppression of other $\mathrm{T}$ cells suits their role of sustaining self-tolerance, but potentially hinders tumor immunity or the proper work of the acquired immune system in viral defense. Another speculation is that the peripheral conversion of $\mathrm{CD} 4+\mathrm{T}$ cells into $\mathrm{T}_{\text {reg }}$ cells could be induced by microbial, particularly viral, infection. The association of some chronic viral infections with pulmonary hypertension is well known $[52,58,59]$, and some findings point toward a potential role of microbial (mainly viral) antigen mimicry in the pathogenesis of IPAH [60], although to date, no specific microbial antigen could be consistently demonstrated $[61,62]$. Besides an increase in $\mathrm{T}_{\text {reg }}$ cells, in the present study, we also found a significant decrease in $\mathrm{CD} 8+\mathrm{T}$ cells. A decreased number or impaired function of CD8+ T cells (so called exhausted $\mathrm{T}$ cells) has been described in chronic viral infections [63- 
66]. It is conceivable that a yet unknown factor in chronic viral infections of the pulmonary vasculature in PAH would trigger a depletion of cytotoxic $\mathrm{T}$ cells along with an increase in $\mathrm{T}_{\text {reg }}$ cells. Moreover, such a viral infection might also provoke the expression of epitopes on immune or endothelial cells against which an altered immune response in PAH might be directed. Future studies with a focus on the detection of viral or self antigens in the pulmonary vasculature against which the altered $\mathrm{T}$ cell subsets are directed would be desirable.

Plexiform lesions in lung tissue of patients with pulmonary hypertension are not only surrounded by lymphocytes and mast cells [21,67], but also by dendritic cells (DCs), as has been described recently [68]. DCs play a role in immune regulation as professional antigen-presenting cells and controllers of the differentiation of naïve $\mathrm{T}$ cells into $\mathrm{T}_{\text {reg }}$ cells $[69,70]$. Whereas inflammatory stimuli induce DC maturation, which direct naïve $\mathrm{T}$ cells to differentiate into effector T cells, immature DCs were only recently acknowledged to have an important role in the maintenance of immune tolerance through induction of $\mathrm{T}_{\text {reg }}$ cells $[69,71,72]$. On the other hand, $\mathrm{T}_{\text {reg }}$ cells talk back to DCs restraining their maturation and antigen presentation [73]. Therefore, it could be hypothesized that our finding and the finding of Perros et al. [68] point towards a mutual interaction between $\mathrm{T}_{\text {reg }}$ cells and DCs in order to keep up a state of tolerance. It remains to be questioned at which time point in the course of the disease such a state of tolerance develops, e.g., it could be imagined that an autoimmune constellation early in the disease course would later on develop into a state of tolerance with increased $\mathrm{T}_{\text {reg }}$ cells and DCs. However, in our study population, we found no difference between lymphocyte subsets obtained from patients within 10 months of the initial right heart catheterization and lymphocyte subsets obtained from patients with a time span of more than 10 month from diagnosis, although our study was not designed to look at changes of lymphocyte subsets over time.

The association of $\mathrm{PAH}$ with various autoimmune disorders is well known $[8,9,24,74-78]$, and findings such as anti-endothelial cell or anti-fibroblast antibodies in patients with IPAH or scleroderma-associated PAH suggest a pathogenetic role of autoimmunity in PAH $[19,20]$. As many autoimmune diseases have been found to be associated with decreased $\mathrm{T}_{\text {reg }}$ cells $[36,40,46,49,79]$, our findings of increased $\mathrm{T}_{\text {reg }}$ cells might be unexpected. Possible explanations could be that $\mathrm{T}_{\text {reg }}$ cells in the peripheral blood would be reactively elevated, along with a possible decrease in $\mathrm{T}_{\text {reg }}$ cells early in the disease course, or that, as discussed above, the increased $\mathrm{T}_{\text {reg }}$ cells represent some state of immune tolerance in the course of the disease, possibly induced by a tumor or infectious antigen, leading to cancer-like proliferations in the pulmonary vasculature $[46,55]$.

Another possibility would be that the difference in lymphocyte subsets between our patients and controls could be attributed to simple confounders like age, gender or drug use. Patients were on average slightly older and more likely to be female than controls. In normal humans, total lymphocyte count, $\mathrm{CD} 8+\mathrm{T}$ and $\mathrm{CD} 19+\mathrm{B}$ cell subsets have been described to decrease beyond the age of 50 years, whereas female sex is related to higher CD4+ T cells [80], data on $\mathrm{T}_{\text {reg }}$ cells is lacking. As our patients were on average slightly older than 50 years $(51 \pm 11)$, it cannot be excluded that some of the differences we found between patients and controls could be attributed to age.

Drug use might alter $\mathrm{T}_{\text {reg }}$ cell number and possibly activity as well. Steroids have been found to increase $T_{\text {reg }}$ cells $[81,82]$; therefore, we included only steroid-naïve patients. Nevertheless, specific drugs used in the treatment of PAH (such as prostanoids, endothelin receptor antagonists or phosphodieasterase inhibitors) have a potential to influence immune regulation and thereby lymphocyte subsets [83-86]. Sixty-eight percent of the patients in our cohort were on continuous intravenous epoprostenol therapy. All the same, we did not find a difference in lymphocyte subsets between treated and untreated patients. However, this study was not designed to look for effects of therapy on lymphocyte subsets; therefore, it could still be possible that some of the observed differences between patients and controls can be attributed to therapy. Future studies are warranted to answer questions about the influence of therapy on lymphocyte subsets.

In summary, we believe that our findings of increased $\mathrm{T}_{\text {reg }}$ cells and decreased CD8 $+\mathrm{T}$ cells in the peripheral blood of patients with IPAH are important and may have significant implications in directing future research in the field. Whether alterations in lymphocyte subsets actually play a role in the pathobiology of PAH and whether they are a cause or a consequence remains to be investigated.

\section{Acknowledgement}

We thank the Offspring-Sponsoring-Foundation of the University of Zurich for supporting S.U. 


\section{References}

1 Humbert M, Morrell NW, Archer SL, Stenmark KR, MacLean MR, Lang IM, Christman BW, Weir EK, Eickelberg O, Voelkel NF, Rabinovitch M: Cellular and molecular pathobiology of pulmonary arterial hypertension. J Am Coll Cardiol 2004;43:13S24S.

$\checkmark 2$ Tuder RM, Cool CD, Yeager M, Taraseviciene-Stewart L, Bull TM, Voelkel NF: The pathobiology of pulmonary hypertension. Endothelium. Clin Chest Med 2001;22:405418.

>3 Voelkel NF, Cool C: Pathology of pulmonary hypertension. Cardiol Clin 2004;22:343351, v.

$\checkmark 4$ Lane KB, Machado RD, Pauciulo MW, Thomson JR, Phillips JA 3rd, Loyd JE, Nichols WC, Trembath RC: Heterozygous germline mutations in BMPR2, encoding a TGF- $\beta$ receptor, cause familial primary pulmonary hypertension. The International PPH Consortium. Nat Genet 2000;26:81-84.

$\checkmark 5$ Newman JH, Trembath RC, Morse JA, Grunig E, Loyd JE, Adnot S, Coccolo F, Ventura C, Phillips JA 3rd, Knowles JA, Janssen B, Eickelberg O, Eddahibi S, Herve P, Nichols WC, Elliott G: Genetic basis of pulmonary arterial hypertension: current understanding and future directions. J Am Coll Cardiol 2004;43:33S-39S

6 Thomson JR, Machado RD, Pauciulo MW, Morgan NV, Humbert M, Elliott GC, Ward K, Yacoub M, Mikhail G, Rogers P, Newman J, Wheeler L, Higenbottam T, Gibbs JS, Egan J, Crozier A, Peacock A, Allcock R, Corris P, Loyd JE, Trembath RC, Nichols WC: Sporadic primary pulmonary hypertension is associated with germline mutations of the gene encoding BMPR-II, a receptor member of the TGF- $\beta$ family. J Med Genet 2000;37:741745 .

7 Sztrymf B, Yaici A, Girerd B, Humbert M: Genes and pulmonary arterial hypertension. Respiration 2007;74:123-132.

8 Nicolls MR, Taraseviciene-Stewart L, Rai PR, Badesch DB, Voelkel NF: Autoimmunity and pulmonary hypertension: a perspective. Eur Respir J 2005;26:1110-1118.

-9 Carreira PE: Pulmonary hypertension in autoimmune rheumatic diseases. Autoimmun Rev 2004;3:313-320.

10 Gurubhagavatula I, Palevsky HI: Pulmonary hypertension in systemic autoimmune disease. Rheum Dis Clin North Am 1997;23: 365-394.

$>11$ Kondo H: Autoimmune aspects of pulmonary hypertension in collagen vascular diseases. Intern Med 2003;42:1163-1164.

-12 Magliano M, Isenberg DA, Hillson J: Pulmonary hypertension in autoimmune rheumatic diseases: where are we now? Arthritis Rheum 2002;46:1997-2009.
13 Rabinovitch M: Autoimmune disease and unexplained pulmonary hypertension. Cir culation 1992;85:380-381.

14 Yanai-Landau H, Amital H, Bar-Dayan Y, Levy Y, Gur H, Lin HC, Alosachie IJ, Peter JB, Shoenfeld Y: Autoimmune aspects of primary pulmonary hypertension. Pathobiology 1995;63:71-75.

15 Tew MB, Arnett FC, Reveille JD, Tan FK: Mutations of bone morphogenetic protein receptor type II are not found in patients with pulmonary hypertension and underlying connective tissue diseases. Arthritis Rheum 2002;46:2829-2830.

16 Rosenbaum J, Pottinger BE, Woo P, Black CM, Loizou S, Byron MA, Pearson JD: Measurement and characterisation of circulating anti-endothelial cell IgG in connective tissue diseases. Clin Exp Immunol 1988;72:450456.

17 Negi VS, Tripathy NK, Misra R, Nityanand S: Antiendothelial cell antibodies in scleroderma correlate with severe digital ischemia and pulmonary arterial hypertension. J Rheumatol 1998;25:462-466.

18 Wusirika R, Ferri C, Marin M, Knight DA, Waldman WJ, Ross P Jr, Magro CM: The assessment of anti-endothelial cell antibodies in scleroderma-associated pulmonary fibrosis. A study of indirect immunofluorescent and Western blot analysis in 49 patients with scleroderma. Am J Clin Pathol 2003;120 596-606.

19 Tamby MC, Chanseaud Y, Humbert M, Fermanian J, Guilpain P, Garcia-de-la-PenaLefebvre P, Brunet S, Servettaz A, Weill B, Simonneau G, Guillevin L, Boissier MC, Mouthon L: Anti-endothelial cell antibodies in idiopathic and systemic sclerosis associated pulmonary arterial hypertension. Tho$\operatorname{rax} 2005 ; 60: 765-772$.

20 Tamby MC, Humbert M, Guilpain P, Servettaz A, Dupin N, Christner JJ, Simonneau G, Fermanian J, Weill B, Guillevin L, Mouthon L: Antibodies to fibroblasts in idiopathic and scleroderma-associated pulmonary hyper tension. Eur Respir J 2006;28:799-807.

-21 Tuder RM, Groves B, Badesch DB, Voelkel NF: Exuberant endothelial cell growth and elements of inflammation are present in plexiform lesions of pulmonary hypertension. Am J Pathol 1994;144:275-285.

22 Tuder RM, Voelkel NF: Angiogenesis and pulmonary hypertension: a unique process in a unique disease. Antioxid Redox Signal 2002;4:833-843.

23 Voelkel NF, Tuder RM: Cellular and molecular mechanisms in the pathogenesis of severe pulmonary hypertension. Eur Respir J 1995; 8:2129-2138.

24 Dorfmuller P, Perros F, Balabanian K, Humbert M: Inflammation in pulmonary arterial hypertension. Eur Respir J 2003;22:358363.
25 Tsunemi S, Iwasaki T, Imado T, Higasa S, Kakishita E, Shirasaka T, Sano H: Relationship of $\mathrm{CD} 4+\mathrm{CD} 25+$ regulatory $\mathrm{T}$ cells to immune status in HIV-infected patients. AIDS 2005;19:879-886.

26 Taraseviciene-Stewart L, Scerbavicius DK, Burns N, Cool CD, Nicolls MR, Voelkel NF: The protective role of T-lymphocytes in pulmonary vascular remodeling. Chest 2005; 128:571S-572S

$\checkmark 27$ Taraseviciene-Stewart L, Nicolls MR, Kraskauskas D, Scerbavicius R, Burns N, Cool C, Wood K, Parr JE, Boackle SA, Voelkel NF: Absence of T cells confers increased pulmonary arterial hypertension and vascular remodeling. Am J Respir Crit Care Med 2007; 175:1280-1289.

28 Taraseviciene-Stewart L, Kasahara Y, Alger L, Hirth P, Mc Mahon G, Waltenberger J, Voelkel NF, Tuder RM: Inhibition of the VEGF receptor 2 combined with chronic hypoxia causes cell death-dependent pulmonary endothelial cell proliferation and severe pulmonary hypertension. FASEB J 2001;15: 427-438.

29 Burnet F: The Clonal Selection Theory of Acquired Immunity. Cambridge, Cambridge University Press, 1959.

30 Sakaguchi S: Regulatory T cells: key controllers of immunologic self-tolerance. Cell 2000;101:455-458

31 Sakaguchi S, Sakaguchi N, Asano M, Itoh M, Toda M: Immunologic self-tolerance maintained by activated $\mathrm{T}$ cells expressing IL-2 receptor $\alpha$-chains (CD25). Breakdown of a single mechanism of self-tolerance causes various autoimmune diseases. J Immunol 1995; 155:1151-1164

32 Shevach EM: Certified professionals: CD4 (+)CD25(+)suppressor T cells. J Exp Med 2001;193:F41-F46.

33 Fontenot JD, Gavin MA, Rudensky AY: Foxp3 programs the development and function of CD4+CD25+ regulatory T cells. Nat Immunol 2003;4:330-336.

34 Hori S, Nomura T, Sakaguchi S: Control of regulatory $\mathrm{T}$ cell development by the transcription factor Foxp3. Science 2003;299: 1057-1061.

35 Kasprowicz DJ, Droin N, Soper DM, Ramsdell F, Green DR, Ziegler SF: Dynamic regulation of FoxP3 expression controls the balance between CD4+ T cell activation and cell death. Eur J Immunol 2005;35:3424-3432.

36 Sakaguchi S, Sakaguchi N: Regulatory T cells in immunologic self-tolerance and autoimmune disease. Int Rev Immunol 2005; 24:211-226

37 Sakaguchi S: Naturally arising CD4+ regulatory $\mathrm{T}$ cells for immunologic self-tolerance and negative control of immune responses. Annu Rev Immunol 2004;22:531-562. 
-38 Sakaguchi S, Takahashi T, Yamazaki S, Kuniyasu Y, Itoh M, Sakaguchi N, Shimizu J: Immunologic self tolerance maintained by T-cell-mediated control of self-reactive $\mathrm{T}$ cells: implications for autoimmunity and tumor immunity. Microbes Infect 2001;3:911918.

- 39 Boyer O, Saadoun D, Abriol J, Dodille M, Piette JC, Cacoub P, Klatzmann D: $\mathrm{CD} 4+\mathrm{CD} 25+$ regulatory $\mathrm{T}$-cell deficiency in patients with hepatitis C-mixed cryoglobulinemia vasculitis. Blood 2004; 103:34283430.

-40 Crispin JC, Martinez A, Alcocer-Varela J: Quantification of regulatory $\mathrm{T}$ cells in patients with systemic lupus erythematosus. J Autoimmun 2003;21:273-276.

-41 Terabe M, Berzofsky JA: Immunoregulatory $\mathrm{T}$ cells in tumor immunity. Curr Opin Immunol 2004;16:157-162.

-42 Wolf AM, Wolf D, Steurer M, Gastl G, Gunsilius E, Grubeck-Loebenstein B: Increase of regulatory $\mathrm{T}$ cells in the peripheral blood of cancer patients. Clin Cancer Res 2003;9: 606-612.

-43 Cesana GC, DeRaffele G, Cohen S, Moroziewicz D, Mitcham J, Stoutenburg J, Cheung K, Hesdorffer C, Kim-Schulze S, Kaufman HL: Characterization of CD4+CD25+ regulatory $T$ cells in patients treated with high-dose interleukin-2 for metastatic melanoma or renal cell carcinoma. J Clin Oncol 2006;24:1169_ 1177.

-44 Yang XH, Yamagiwa S, Ichida T, Matsuda Y, Sugahara S, Watanabe H, Sato Y, Abo T, Horwitz DA, Aoyagi Y: Increase of $\mathrm{CD} 4(+)$ $\mathrm{CD} 25(+)$ regulatory T-cells in the liver of patients with hepatocellular carcinoma. J Hepatol 2006;45:178-181.

-45 Ormandy LA, Hillemann T, Wedemeyer H, Manns MP, Greten TF, Korangy F: Increased populations of regulatory $\mathrm{T}$ cells in peripheral blood of patients with hepatocellular carcinoma. Cancer Res 2005;65:2457-2464.

46 Danese S, Rutella S: The Janus face of CD4+CD25+ regulatory $\mathrm{T}$ cells in cancer and autoimmunity. Curr Med Chem 2007; 14:649-666.

-47 Liu MF, Wang CR, Fung LL, Wu CR: Decreased CD4+CD25+ T cells in peripheral blood of patients with systemic lupus erythematosus. Scand J Immunol 2004;59:198202.

48 Yudoh K, Matsuno H, Nakazawa F, Yonezawa T, Kimura T: Reduced expression of the regulatory $\mathrm{CD} 4+\mathrm{T}$ cell subset is related to Th1/Th2 balance and disease severity in rheumatoid arthritis. Arthritis Rheum 2000; 43:617-627.

49 Jonuleit H, Schmitt E: The regulatory T cell family: distinct subsets and their interrelations. J Immunol 2003;171:6323-6327.
50 Franzese O, Kennedy PT, Gehring AJ, Gotto J, Williams R, Maini MK, Bertoletti A: Modulation of the $\mathrm{CD} 8+\mathrm{T}$-cell response by $\mathrm{CD} 4+$ $\mathrm{CD} 25+$ regulatory $\mathrm{T}$ cells in patients with hepatitis B virus infection. J Virol 2005;79: 3322-3328.

51 Walsh PT, Benoit BM, Wysocka M, Dalton NM, Turka LA, Rook AH: A role for regulatory $\mathrm{T}$ cells in cutaneous T-cell lymphoma; induction of a CD4+ CD25+ Foxp3+ T-cell phenotype associated with HTLV-1 infection. J Invest Dermatol 2006;126:690-692.

-52 Simonneau G, Galie N, Rubin LJ, Langleben D, Seeger W, Domenighetti G, Gibbs S, Lebrec D, Speich R, Beghetti M, Rich S, Fishman A: Clinical classification of pulmonary hypertension. J Am Coll Cardiol 2004;43: $5 \mathrm{~S}-12 \mathrm{~S}$.

53 Walker MR, Kasprowicz DJ, Gersuk VH, Benard A, Van Landeghen M, Buckner JH, Ziegler SF: Induction of FoxP3 and acquisition of $\mathrm{T}$ regulatory activity by stimulated human CD4+CD25- T cells. J Clin Invest 2003;112:1437-1443.

54 Sakaguchi S: Immunologic tolerance maintained by regulatory T cells: implications for autoimmunity, tumor immunity and transplantation tolerance. Vox Sang 2002;83 (suppl 1):151-153.

55 Voelkel NF, Cool C, Lee SD, Wright L, Geraci MW, Tuder RM: Primary pulmonary hypertension between inflammation and cancer. Chest 1998;114:225S-230S.

56 Dunn GP, Old LJ, Schreiber RD: The three Es of cancer immunoediting. Annu Rev Immunol 2004;22:329-360.

57 Van Der Bruggen P, Zhang Y, Chaux P, Stroobant V, Panichelli C, Schultz ES, Chapiro J, Van Den Eynde BJ, Brasseur F, Boon T: Tumor-specific shared antigenic peptides recognized by human T cells. Immunol Rev 2002;188:51-64

58 Opravil M, Pechere M, Speich R, Joller-Jemelka HI, Jenni R, Russi EW, Hirschel B, Luthy R: HIV-associated primary pulmonary hypertension. A case control study. Swiss HIV Cohort Study. Am J Respir Crit Care Med 1997;155:990-995.

59 Speich R, Jenni R, Opravil M, Pfab M, Russi EW: Primary pulmonary hypertension in HIV infection. Chest 1991;100:1268-1271.

60 Marecki J, Cool C, Voelkel N, Luciw P, Flores $\mathrm{S}$ : Evidence for vascular remodeling in the lungs of macaques infected with simian immunodeficiency virus/HIV NEF recombinant virus. Chest 2005;128:621S-622S

61 Bendayan D, Sarid R, Cohen A, Shitrit D, Shechtman I, Kramer MR: Absence of human herpesvirus 8 DNA sequences in lung biopsies from Israeli patients with pulmonary arterial hypertension. Respiration 2008;75:155-157.
62 Cool CD, Rai PR, Yeager ME, HernandezSaavedra D, Serls AE, Bull TM, Geraci MW, Brown KK, Routes JM, Tuder RM, Voelkel NF: Expression of human herpesvirus 8 in primary pulmonary hypertension. $\mathrm{N}$ Engl J Med 2003;349:1113-1122.

63 Barber DL, Wherry EJ, Masopust D, Zhu B, Allison JP, Sharpe AH, Freeman GJ, Ahmed R: Restoring function in exhausted CD8 T cells during chronic viral infection. Nature 2006;439:682-687.

64 Wherry EJ, Blattman JN, Ahmed R: Low CD8 T-cell proliferative potential and high viral load limit the effectiveness of therapeutic vaccination. J Virol 2005;79:8960-8968.

65 Kaech SM, Hemby S, Kersh E, Ahmed R: Molecular and functional profiling of memory CD8 T cell differentiation. Cell 2002;111: 837-851.

66 Klenerman P, Hill A: T cells and viral persistence: lessons from diverse infections. Nat Immunol 2005;6:873-879.

67 Heath D, Yacoub M: Lung mast cells in plexogenic pulmonary arteriopathy. J Clin Pathol 1991;44:1003-1006.

68 Perros F, Dorfmuller P, Souza R, DurandGasselin I, Mussot S, Mazmanian M, Herve P, Emilie D, Simonneau G, Humbert M: Dendritic cell recruitment in lesions of human and experimental pulmonary hypertension. Eur Respir J 2007;29:462-468.

69 Jonuleit H, Schmitt E, Steinbrink K, Enk AH: Dendritic cells as a tool to induce anergic and regulatory T cells. Trends Immunol 2001;22: 394-400.

-70 Steinbrink K, Wolfl M, Jonuleit H, Knop J, Enk AH: Induction of tolerance by IL-10treated dendritic cells. J Immunol 1997;159: 4772-4780.

-71 Jonuleit H, Schmitt E, Schuler G, Knop J, Enk $\mathrm{AH}$ : Induction of interleukin 10-producing, nonproliferating CD4 (+) T cells with regulatory properties by repetitive stimulation with allogeneic immature human dendritic cells. J Exp Med 2000;192:1213-1222.

72 Mahnke K, Johnson TS, Ring S, Enk AH: Tolerogenic dendritic cells and regulatory $\mathrm{T}$ cells: a two-way relationship. J Dermatol Sci 2007;46:159-167.

73 Misra N, Bayry J, Lacroix-Desmazes S, Kazatchkine MD, Kaveri SV: Cutting edge: human CD4+CD25+ T cells restrain the maturation and antigen-presenting function of dendritic cells. J Immunol 2004;172:46764680.

-74 Battle RW, Davitt MA, Cooper SM, Buckley LM, Leib ES, Beglin PA, Tischler MD: Prevalence of pulmonary hypertension in limited and diffuse scleroderma. Chest 1996;110: 1515-1519.

75 Fagan KA, Badesch DB: Pulmonary hypertension associated with connective tissue disease. Prog Cardiovasc Dis 2002;45:225234 
-76 MacGregor AJ, Canavan R, Knight C, Denton CP, Davar J, Coghlan J, Black CM: Pulmonary hypertension in systemic sclerosis: risk factors for progression and consequences for survival. Rheumatology (Oxford) 2001;40:453-459.

-77 Sacks DG, Okano Y, Steen VD, Curtiss E, Shapiro LS, Medsger TA Jr: Isolated pulmonary hypertension in systemic sclerosis with diffuse cutaneous involvement: association with serum anti-U3RNP antibody. J Rheumatol 1996;23:639-642.

-78 Salerni R, Rodnan GP, Leon DF, Shaver JA: Pulmonary hypertension in the CREST syndrome variant of progressive systemic sclerosis (scleroderma). Ann Intern Med 1977; 86:394-399.

79 Thomas D, Zaccone P, Cooke A: The role of regulatory $\mathrm{T}$ cell defects in type I diabetes and the potential of these cells for therapy. Rev Diabet Stud 2005;2:9-18.
80 Jentsch-Ullrich K, Koenigsmann M, Mohren M, Franke A: Lymphocyte subsets' reference ranges in an age- and gender-balanced population of 100 healthy adults - a monocentric German study. Clin Immunol 2005; 116:192197.

81 Page ST, Plymate SR, Bremner WJ, Matsumoto AM, Hess DL, Lin DW, Amory JK, Nelson PS, Wu JD: Effect of medical castration on CD4+ CD25+ T cells, CD8+ T cell IFN- $\gamma$ expression, and NK cells: a physiological role for testosterone and/or its metabolites. Am J Physiol Endocrinol Metab 2006;290:E856E863.

82 Suarez A, Lopez P, Gomez J, Gutierrez C: Enrichment of CD4+ CD25high T cell population in patients with systemic lupus erythematosus treated with glucocorticoids. Ann Rheum Dis 2006;65:1512-1517.
83 Badesch DB, McLaughlin VV, Delcroix M, Vizza CD, Olschewski H, Sitbon O, Barst RJ: Prostanoid therapy for pulmonary arterial hypertension. J Am Coll Cardiol 2004;43: 56S-61S.

84 Channick RN, Sitbon O, Barst RJ, Manes A, Rubin LJ: Endothelin receptor antagonists in pulmonary arterial hypertension. J Am Coll Cardiol 2004;43:62S-67S.

85 Galie N, Ghofrani HA, Torbicki A, Barst RJ, Rubin LJ, Badesch D, Fleming T, Parpia T, Burgess G, Branzi A, Grimminger F, Kurzyna M, Simonneau G: Sildenafil citrate therapy for pulmonary arterial hypertension. $\mathrm{N}$ Engl J Med 2005;353:2148-2157.

86 Bargagli E, Galeazzi M, Bellisai F, Volterrani L, Rottoli P: Infliximab treatment in a patient with systemic sclerosis associated with lung fibrosis and pulmonary hypertension. Respiration 2008;75:346-349. 